\title{
Type II cyclic guanosine monophosphate-dependent protein kinase inhibits epidermal growth factor receptor activation in different cancer cell lines
}

\author{
LU JIANG, MIN WU, YAN WU, TING LAN, YING WANG, HAI QIAN and YONGCHANG CHEN \\ Department of Physiology, School of Medicine, Jiangsu University, Zhenjiang, Jiangsu 212013, P.R. China
}

Received June 13, 2014; Accepted February 6, 2015

DOI: $10.3892 / \mathrm{ol} .2015 .3067$

\begin{abstract}
Previous data has revealed that type II cyclic guanosine monophosphate-dependent protein kinase (PKG II) inhibits epidermal growth factor (EGF)-induced phosphorylation/activation of the epidermal growth factor receptor (EGFR) and mitogen-activated protein kinase/extracellular-signal-regulated kinase (MAPK/ERK) in gastric cancer cells. The aim of the present study was to determine whether PKG II inhibited EGF-induced phosphorylation/activation of EGFR and MAPK/ERK in cell lines derived from different cancer tissues. SW480, HepG2, OS-RC-2, A549, MCF-7 and U251 cells were transfected with adenoviral constructs encoding PKG II cDNA (Ad-PKG II) to upregulate the expression of PKG II, and then treated with 8-(4-chlorophenylthio)guanosine 3',5'-cyclic monophosphate (8-pCPT-cGMP) in order to activate the kinase. Western blot analysis was performed to investigate the phosphorylation of EGFR and MAPK/ERK. The results demonstrated that treatment with $100 \mathrm{ng} / \mathrm{ml} \mathrm{EGF}$ for $5 \mathrm{~min}$ increased the tyrosine (Tyr)1068 phosphorylation of EGFR and the threonine 202/Tyr204 phosphorylation of MAPK/ERK. Transfecting the cells with Ad-PKG II, and stimulating the kinases with 8-pCPT-cGMP efficiently inhibited the EGF-induced phosphorylation of EGFR and MAPK/ERK. The results revealed that PKG II had an inhibitory effect upon EGFR activation and the consequent MAPK/ERK-mediated signaling of cell lines derived from the various cancer tissues.
\end{abstract}

\section{Introduction}

Type II cyclic guanosine monophosphate (cGMP)-dependent protein kinase (PKG II) is a serine-threonine kinase that

Correspondence to: Professor Yongchang Chen, Department of Physiology, School of Medicine, Jiangsu University, 301 Xuefu Road, Zhenjiang, Jiangsu 212013, P.R. China

E-mail: ycchen54@ujs.edu.cn

Key words: type II cyclic guanosine monophosphate-dependent protein kinase, epidermal growth factor, receptor, inhibition, cancer cells was first identified $>30$ years ago. Novel functions of this kinase have been revealed, including its role in regulating cellular proliferation and apoptosis (1-3). In addition, previous studies have demonstrated that PKG II may be a potential inhibitor of factors involved in the pathogenesis of cancer. It has been reported that PKG II can inhibit the proliferation of human neuroglioma and colonic cancer cells $(2,4)$. In addition, previous data has demonstrated that PKG II inhibits the proliferation, migration and associated signal transduction pathways of gastric cancer cell lines through blocking the phosphorylation/activation of the epidermal growth factor receptor (EGFR) and consequent signaling initiated by the activation of this receptor $(5,6)$. Whether or not PKG II demonstrates similar inhibitory effects in other cancer cell lines deserves further investigation. The present study aimed to elucidate whether PKG II inhibits epidermal growth factor (EGF)-induced phosphorylation/activation of EGFR and signaling mediated by mitogen-activated protein kinase/extracellular signal-regulated kinase (MAPK/ERK) in cell lines derived from different cancer tissues, namely the colon cancer SW480 cell line, the hepatic cancer HepG2 cell line, the kidney cancer OS-RC-2 cell line, the lung cancer A549 cell line, the breast cancer MCF-7 cell line and the neuronal cancer U251 cell line.

\section{Materials and methods}

Cell lines and reagents. The SW480, HepG2, OS-RC-2, A549, MCF7 and U251 cancer cell lines were obtained from the Institute of Cell Biology (Shanghai, China). In addition, 293A cells were obtained from the Institute of Cell Biology. The adenoviral vectors encoding the cDNA of $\beta$-galactosidase (Ad-LacZ) and PKG II (Ad-PKG II) were kindly provided by Dr Gerry Boss and Dr Renate Pilz from the University of California (San Diego, USA). The Dulbecco's modified Eagle's medium (DMEM) and fetal bovine serum (FBS) were purchased from Gibco Life Technologies (Carlsbad, CA, USA). Polyclonal rabbit anti-human PKG II antibody (1:200) was obtained from Abgent, Inc. (San Diego, CA, USA), and polyclonal rabbit anti-human EGFR antibody (1:200) was purchased from Santa Cruz Biotechnology, Inc. (Dallas, TX, USA). Monoclonal mouse anti-human p-EGFR [tyrosine (Tyr)1068; 1:200], polyclonal rabbit anti-human p-ERK1/2 [threonine (Thr)202/Tyr 204; 1:200] and polyclonal rabbit 
anti-human ERK1/2 antibodies (1:200) were obtained from Cell Signaling Technology, Inc. (Danvers, MA, USA). Polyclonal horseradish peroxidase-conjugated goat anti-rabbit and goat anti-mouse IgG secondary antibodies $(1: 10,000)$ were purchased from Jackson ImmunoResearch Laboratories, Inc. (West Grove, PA, USA). The cellular permeable cGMP analog, 8-(4-chlorophenylthio)guanosine 3',5'-cyclic monophosphate (8-pCPT-cGMP), was obtained from EMD Millipore (Billerica, MA, USA). The recombinant human EGF was purchased from PeproTech, Inc., (Rocky Hill, NJ, USA) and the electrochemiluminescence (ECL) reagents were obtained from EMD Millipore. All other reagents used were of analytical grade.

Preparation of adenoviral vectors. 293A cells were transfected with an adenoviral vector encoding either PKG II or LacZ. Next, the cells were cultured for up to 10 days until a cytopathic effect was observed. The cells and culture medium were then harvested and subjected to three cycles of freeze-thawing. The supernatants, containing Ad-LacZ and Ad-PKG II, were then used to transfect new 293A cells and amplify the adenoviruses. Finally, the amplified adenoviral preparations were titrated and the number of plaque-forming units/ $\mathrm{ml}$ was determined. The preparations were then kept at $-80^{\circ} \mathrm{C}$ until use.

Cell culture and infection with adenoviral vectors. The SW480, HepG2, OS-RC-2, A549, MCF7 and U251 cells were cultured in DMEM supplemented with $10 \% \mathrm{FBS}$ and maintained at $37^{\circ} \mathrm{C}$ in a humidified incubator with $95 \%$ air and $5 \% \mathrm{CO}_{2}$. Fresh medium was supplied every two days, and the cells were sub-cultured upon reaching confluency. On the day prior to transfection, the cells were freshly plated at $70-80 \%$ confluence.

Cell transfection. To investigate the inhibitory effect of PKG II on cancer cells, the SW480, HepG2, OS-RC-2, A549, MCF7 and U251 cells were transfected with Ad-PKG II to increase the expression of PKG II or Ad-LacZ as a control, and treated with 8-pCPT-cGMP to activate the kinase and EGF to activate EGFR and ERK. To perform viral transfection, the SW480, HepG2, OS-RC-2, A549, MCF7 and U251 cells $\left(1 \times 10^{7}\right.$ cells/well $)$ were seeded onto six-well culture plates. After $24 \mathrm{~h}$, the cells were transfected with Ad-LacZ or Ad-PKG II with a multiplicity of infection of $100 \%$. To obtain the control group, cells were transfected with LacZ for $48 \mathrm{~h}$ then serum starved overnight. To obtain Ad-LacZ + EGF and PKG II + EGF groups, the cells were transfected with Ad-LacZ and Ad-PKG II, respectively, for $48 \mathrm{~h}$, serum starved overnight and incubated with $100 \mathrm{ng} / \mathrm{ml}$ EGF for $5 \mathrm{~min}$. To obtain Ad-LacZ + cGMP + EGF and Ad-PKG II + cGMP + EGF groups, the cells were transfected with Ad-LacZ and Ad-PKG II respectively, for $48 \mathrm{~h}$, starved of serum overnight, treated with 8-pCPT-cGMP $(100 \mu \mathrm{M}$ or $250 \mu \mathrm{M})$ for $1 \mathrm{~h}$, then treated with $100 \mathrm{ng} / \mathrm{ml} \mathrm{EGF}$ for $5 \mathrm{~min}$. Next, the cells were harvested and the protein extracts were prepared.

Western blotting. The whole cell protein extracts were separated using 10\% SDS-PAGE and then transferred onto a polyvinylidene fluoride membrane. Primary antibodies were then incubated with the membrane at $4^{\circ} \mathrm{C}$ overnight. Next, the corresponding secondary antibodies were incubated at room temperature for $1 \mathrm{~h}$. In total, three washes were performed following each incubation. The ECL reagents were used to observe the positive bands on the membrane. To perform densitometry analysis, digital images (gray levels) of the positive bands were obtained using the ChemiDoc XRS acquisition system (Bio-Rad Laboratories, Inc., Hercules, CA, USA) and analyzed using Quantity One 1-D Analysis software (Bio-Rad Laboratories, Inc.). The results were expressed as the ratio of gray levels of target protein/loading control protein.

Statistical analysis. Data are expressed as the mean \pm standard deviation. Statistical analysis was performed using two-tailed analysis of variance. All statistical analyses were performed using SPSS 13.0 statistical software (SPSS, Inc., Chicago, IL, USA). $\mathrm{P}<0.05$ was considered to indicate a statistically significant difference.

\section{Results}

EGFR and ERK phosphorylation. The binding of EGF to EGFR causes autophosphorylation of the receptor. A number of autophosphorylation sites exist, which are linked to several signal transduction pathways. Tyr1068 is an EGFR autophosphorylation site that is associated with MAPK/ERK-mediated signaling, and that is closely associated with the proliferation and differentiation of cells (7). ERK is a key component of this pathway, and phosphorylation at the Thr202 and Tyr204 residues of ERK1 and the Thr185 and Tyr187 residues of ERK2 is required for complete activation of the enzyme. The present study used western blot analysis to investigate the inhibitory effect of PKG II on the EGF-induced Tyr1068 phosphorylation of EGFR, and the Thr202 and Tyr204 phosphorylation of ERK1/2 in different cell lines.

PKG II inhibits EGF-induced phosphorylation of EGFR and ERK1/2 in SW480 cells. The SW480 cell line was established from a primary adenocarcinoma of the colon from a 50-year-old male (8). In order to investigate the effect of PKG II, the cells were transfected with Ad-PKG II to increase the expression of PKG II, treated with $250 \mu \mathrm{M}$ 8-pCPT-cGMP for $1 \mathrm{~h}$ to activate the kinase, and then treated with $100 \mathrm{ng} / \mathrm{ml} \mathrm{EGF}$ for $5 \mathrm{~min}$. Next, the cells were harvested and the protein extracts were prepared and subjected to western blotting with antibodies against p-EGFR (Tyr1068) and p-ERK1/2 (Thr202/Tyr204). The results revealed that in the cells transfected with Ad-PKG II and stimulated with 8-pCPT-cGMP, the expression of PKG II was markedly increased compared with the Ad-LacZ control group and the EGF-induced phosphorylation of EGFR and ERK1/2 was significantly decreased compared with the Ad-LacZ + EGF group (Fig. 1). This indicated that PKG II could inhibit the EGF-induced phosphorylation/activation of EGFR and ERK1/2.

PKG II inhibits EGF-induced phosphorylation of EGFR and ERK1/2 in HepG2 cells. This HepG2 cell line was established following explant culture of hepatocellular carcinoma tissue from a 15-year-old male (9). The cells were treated in the same manner as the SW480 cells. The results revealed that transfection with Ad-PKG II caused an evident increase in the expression of PKG II (Ad-PKG II groups) when compared with the Ad-LacZ control group. Treatment with $100 \mathrm{ng} / \mathrm{ml} \mathrm{EGF}$ for $5 \mathrm{~min}$ caused marked increases in the phosphorylation of EGFR and ERK1/2 
A

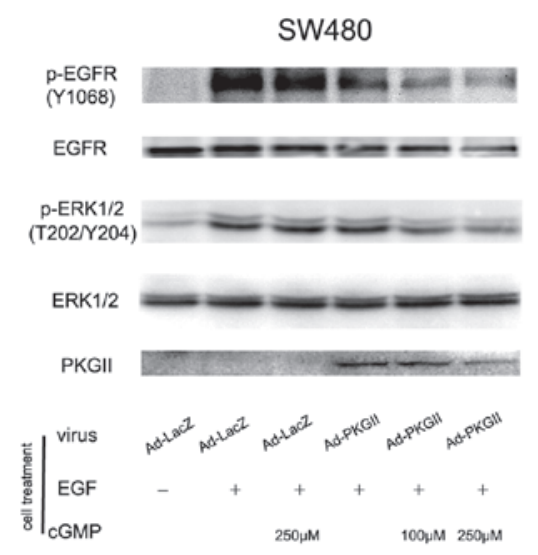

B

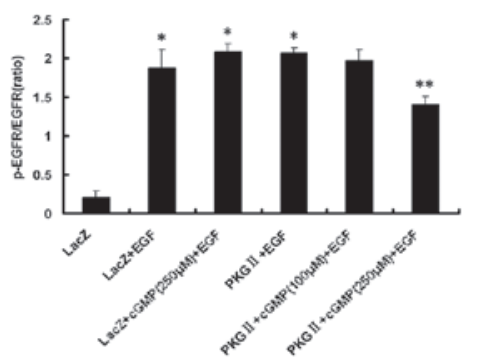

C

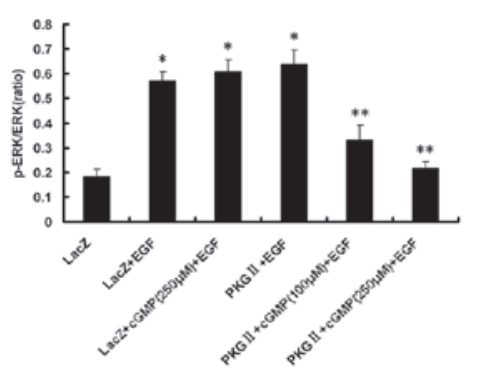

Figure 1. PKG II inhibits the EGF-induced phosphorylation of EGFR and ERK in SW480 cells. SW480 cells were treated as mentioned in the Materials and methods section. (A) Western blotting revealed that transfection with Ad-PKG II caused an evident increase in the expression of PKG II (Ad-PKG II groups) compared with the Ad-LacZ control group. Transfection with EGF induced a marked increase in the phosphorylation of EGFR and ERK (Ad-LacZ + EGF group) compared with the control EGF-negative (Ad-LacZ) group. Treatment with cGMP efficiently inhibited the EGF-induced phosphorylation of EGFR and ERK (Ad-PKG II + cGMP + EGF groups) compared with the Ad-LacZ + EGF group. (B) Ratio of p-EGFR/EGFR gray levels. (C) Ratio of p-ERK/ERK gray levels. ${ }^{*} \mathrm{P}<0.05$ vs. Ad-LacZ control group. ${ }^{* *} \mathrm{P}<0.05$ vs. Ad-LacZ + EGF, Ad-PKG II + cGMP + EGF and PKG II + EGF groups. The results are representative of three separate experiments. cGMP, cyclic guanosine monophosphate; PKG II, type II cGMP-dependent protein kinase; EGF, epidermal growth factor; EGFR, EGF receptor; Ad-LacZ/PKG II, adenoviral vectors encoding $\beta$-galactosidase/PKG II cDNA.

compared with the control EGF-negative group. In cells transfected with Ad-PKG II and stimulated with 8-pCPT-cGMP, EGF-induced phosphorylation of EGFR and ERK1/2 was significantly reduced compared with the Ad-LacZ + EGF control group (Fig. 2). This indicated that PKG II inhibited the EGF-induced phosphorylation/activation of EGFR and ERK1/2 in hepatic cancer cells.

PKG II inhibits EGF-induced phosphorylation of EGFR and ERK1/2 in OS-RC-2 cells. The OS-RC-2 cell line was established from a renal cell carcinoma of a 52-year-old male (10). The inhibitory effect of PKG II on the phosphorylation of
A

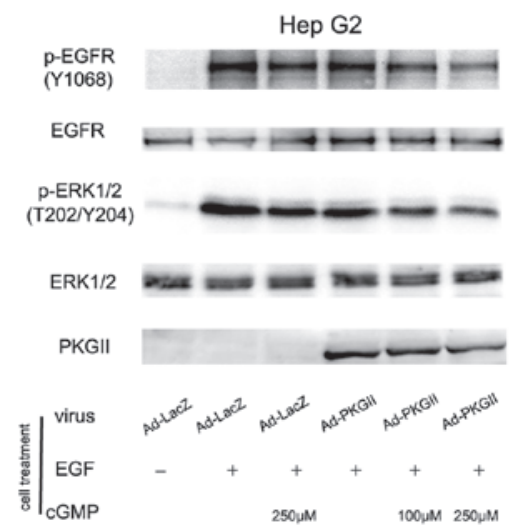

B

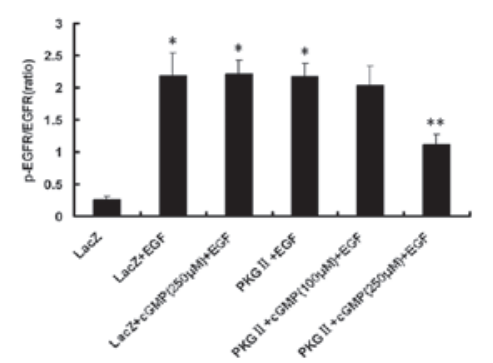

C

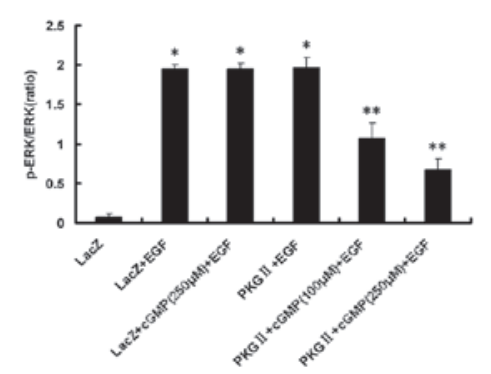

Figure 2. PKG II inhibits the EGF-induced phosphorylation of EGFR and ERK in HepG2 cells. HepG2 cells were treated as described in the Materials and methods section. (A) Western blotting revealed that treatment with EGF induced an evident increase in the phosphorylation of EGFR and ERK (Ad-LacZ + EGF group) compared with the control EGF-negative (Ad-LacZ) group. Transfection with Ad-PKG II+cGMP efficiently inhibited the EGF-induced phosphorylation of EGFR and ERK (Ad-PKG II + cGMP + EGF groups) compared with the Ad-LacZ + cGMP group. (B) Ratio of p-EGFR/EGFR gray levels. (C) Ratio of p-ERK/ERK gray levels. $\mathrm{P}<0.05$ vs. Ad-LacZ control group. ${ }^{* *} \mathrm{P}<0.05$ vs. Ad-LacZ $+\mathrm{EGF}$, Ad-PKG II + cGMP + EGF and PKG II + EGF groups. The results are representative of three separate experiments. cGMP, cyclic guanosine monophosphate; PKG II, type II cGMP-dependent protein kinase; EGF, epidermal growth factor; EGFR, EGF receptor; Ad-LacZ/PKG II, adenoviral vectors encoding $\beta$-galactosidase/PKG II cDNA.

EGFR and ERK1/2 was investigated in the OS-RC-2 cells. The results revealed that transfection with Ad-PKG II caused an evident increase in the expression of PKG II (Ad-PKG II groups) compared with the Ad-LacZ control group. Treatment with $100 \mathrm{ng} / \mathrm{ml}$ EGF for 5 min caused marked increases in the phosphorylation of EGFR and ERK1/2 compared with the control EGF-negative group. In cells transfected with Ad-PKG II and stimulated with 8-pCPT-cGMP, the EGF-induced phosphorylation of EGFR and ERK1/2 was significantly decreased compared with the Ad-LacZ + EGF control group (Fig. 3). This indicated that PKG II inhibited the EGF-induced phosphorylation/activation of EGFR and ERK1/2 in renal cancer cells. 
A

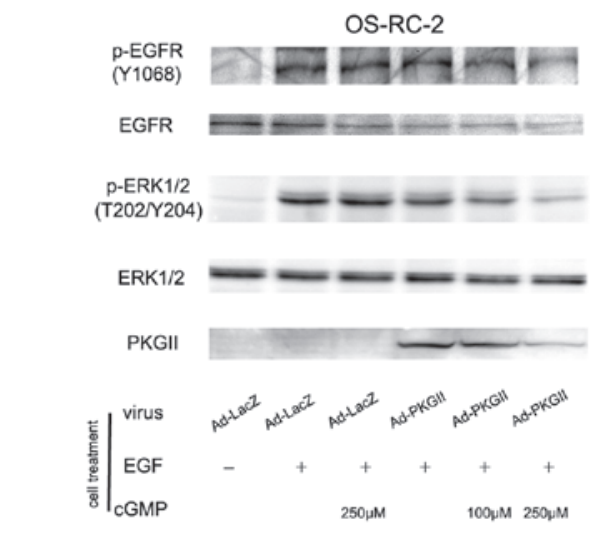

B

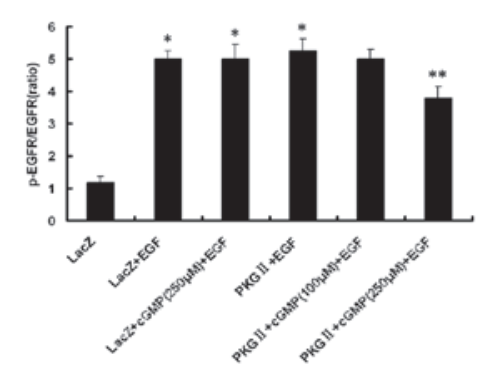

C

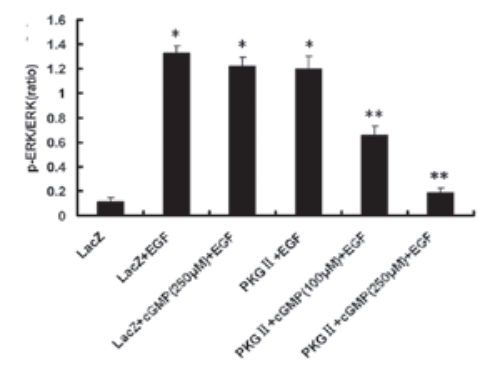

Figure 3. PKG II inhibits the EGF-induced phosphorylation of EGFR and ERK in OS-RC-2 cells. OS-RC-2 cells were treated as described in the Materials and methods section. (A) Western blotting revealed that treatment with EGF induced an evident increase in the phosphorylation of EGFR and ERK (Ad-LacZ + EGF group) compared with the control EGF-negative group. Transfection with Ad-PKG II+cGMP efficiently inhibited the EGF-induced phosphorylation of EGFR and ERK (Ad-PKG II + cGMP + EGF groups) compared with the LacZ + EGF group. (B) Ratio of p-EGFR/EGFR gray levels. (C) Ratio of p-ERK/ERK gray levels. " $\mathrm{P}<0.05$ vs. Ad-LacZ control group. ${ }^{* *} \mathrm{P}<0.05$ vs. Ad-LacZ + EGF, Ad-PKG II + cGMP + EGF and PKG II + EGF groups. The results are representative of three separate experiments. cGMP, cyclic guanosine monophosphate; PKG II, type II cGMP-dependent protein kinase; EGF, epidermal growth factor; EGFR, EGF receptor; Ad-LacZ/ PKG II, adenoviral vectors encoding $\beta$-galactosidase/PKG II cDNA.

PKG II inhibits EGF-induced phosphorylation of EGFR and ERK1/2 in A549 cells. The A549 cell line was established in 1972 by Giard et al (11) through explant culture of lung carcinomatous tissue from a 58-year-old male. The inhibitory effect of PKG II on the phosphorylation of EGFR and ERK1/2 in the A549 cells was investigated using western blotting. The results revealed that transfection with Ad-PKG II (Ad-PKG II group) caused an evident increase in the expression of PKG II compared with the Ad-LacZ control group. Treatment with $100 \mathrm{ng} / \mathrm{ml}$ EGF for 5 min (Ad-LacZ + EGF group) caused a marked increase in the phosphorylation of EGFR and ERK1/2 compared with the control EGF-negative group $(\mathrm{P}<0.05$; Fig. 4). In cells transfected with Ad-PKG II, stimulated with 8-pCPT-cGMP
A

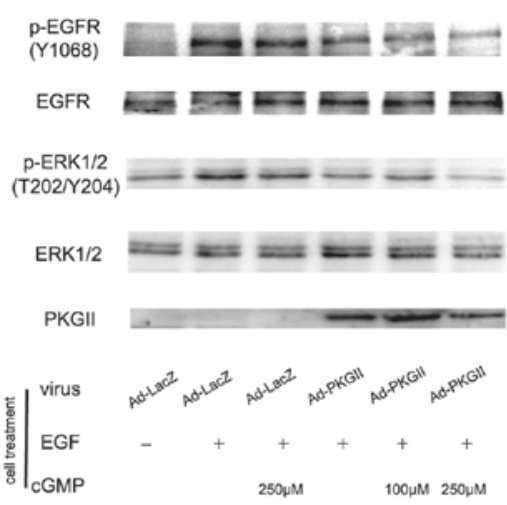

B

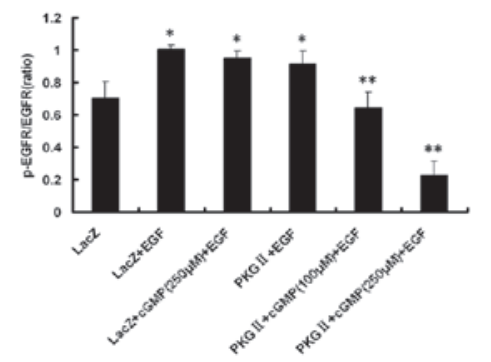

C

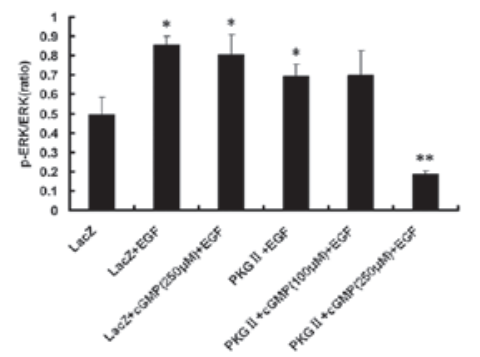

Figure 4. PKG II inhibits the EGF-induced phosphorylation of EGFR and ERK in A549 cells. A549 cells were treated as described in the Materials and methods section. (A) Western blotting revealed that treatment with EGF induced an evident increase in the phosphorylation of EGFR and ERK (Ad-LacZ + EGF group) compared with the control EGF-negative (Ad-LacZ) group. Transfection with Ad-PKG II + cGMP efficiently inhibited the EGF-induced phosphorylation of EGFR and ERK (Ad-PKG II + cGMP + EGF groups) compared with the Ad-LacZ + EGF group. (B) Ratio of p-EGFR/EGFR gray levels. (C) Ratio of $\mathrm{p}-\mathrm{ERK} / \mathrm{ERK}$ gray levels. ${ }^{*} \mathrm{P}<0.05$ vs. Ad-LacZ control group. ${ }^{* *} \mathrm{P}<0.05$ vs. Ad-LacZ + EGF, Ad-PKG II + cGMP + EGF and PKG II + EGF groups. The results are representative of three separate experiments. cGMP, cyclic guanosine monophosphate; PKG II, type II cGMP-dependent protein kinase; EGF, epidermal growth factor; EGFR, EGF receptor; Ad-LacZ/PKG II, adenoviral vectors encoding $\beta$-galactosidase/PKG II cDNA.

and incubated with EGF (Ad-PKG II + cGMP + EGF group), the EGF-induced phosphorylation of EGFR and ERK1/2 was significantly decreased compared with the Ad-LacZ + EGF group $(\mathrm{P}<0.05$; Fig. 4). This indicated that PKG II inhibited the EGF-induced phosphorylation/activation of EGFR and ERK1/2 in lung cancer cells.

PKG II inhibits EGF-induced phosphorylation of EGFR and ERK1/2 in MCF7 cells. The MCF7 cell line was established through explant culture of breast adenocarcinoma tissue from a 69 year-old female (12). The inhibitory effect of PKG II on the phosphorylation of EGFR and ERK1/2 in the MCF7 cells was investigated using western blotting. The results revealed 
$\mathbf{A}$

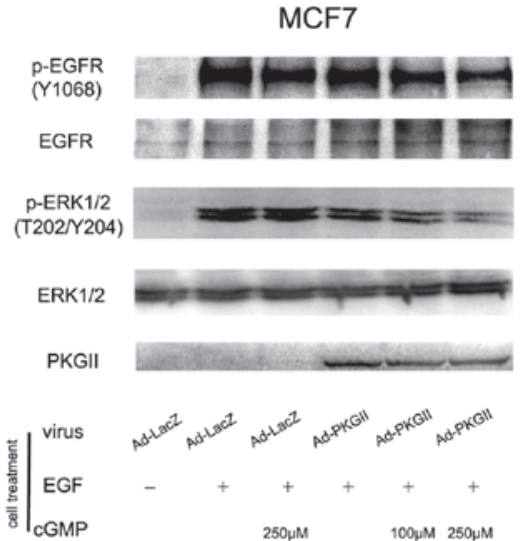

B

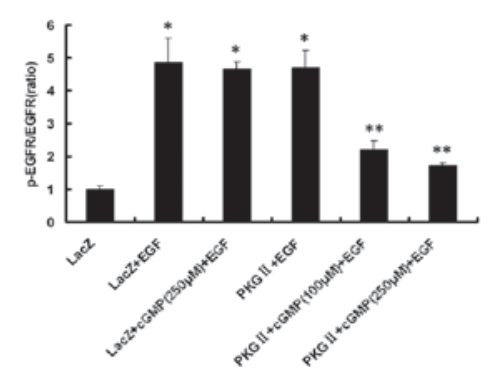

C

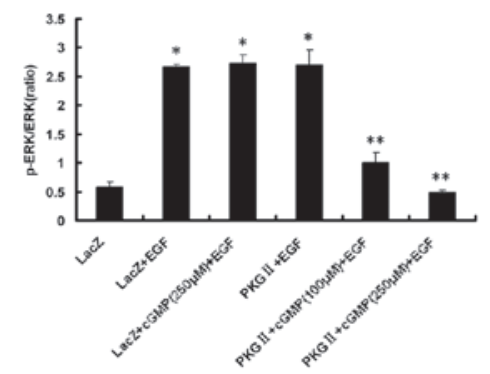

Figure 5. PKG II inhibits the EGF-induced phosphorylation of EGFR and ERK in MCF-7 cells. MCF-7 cells were treated as described in the Materials and methods section. (A) Western blotting revealed that treatment with EGF induced a marked increase in the phosphorylation of EGFR and ERK (Ad-LacZ + EGF group) compared with the control EGF-negative group. Transfection with Ad-PKG II + cGMP efficiently inhibited the EGF-induced phosphorylation of EGFR and ERK (Ad-PKG II + cGMP + EGF groups) compared with the Ad-LacZ + EGF group. (B) Ratio of p-EGFR/EGFR gray levels. (C) Ratio of $\mathrm{p}$-ERK/ERK gray levels. ${ }^{*} \mathrm{P}<0.05$ vs. Ad-LacZ control group. ${ }^{* *} \mathrm{P}<0.05$ vs. Ad-LacZ + EGF, Ad-PKG II + cGMP + EGF and PKG II + EGF groups. The results are representative of three separate experiments. cGMP, cyclic guanosine monophosphate; PKG II, type II cGMP-dependent protein kinase; EGF, epidermal growth factor; EGFR, EGF receptor; Ad-LacZ/PKG II, adenoviral vectors encoding $\beta$-galactosidase/PKG II cDNA.

that transfection with Ad-PKG II (Ad-PKG II group) caused an evident increase in PKG II expression compared with the Ad-LacZ control group. Treatment with $100 \mathrm{ng} / \mathrm{ml}$ EGF for 5 min (Ad-LacZ + EGF group) caused a marked increase in the phosphorylation of EGFR and ERK1/2 compared with the control EGF-negative group $(\mathrm{P}<0.05$; Fig. 5). In cells transfected with Ad-PKG II, stimulated with 8-pCPT-cGMP and incubated with EGF (Ad-PKG II + cGMP + EGF group), the EGF-induced phosphorylation of EGFR and ERK1/2 was significantly decreased compared with the Ad-LacZ + EGF group $(\mathrm{P}<0.05$; Fig. 5). This indicated that $\mathrm{PKG}$ II inhibited the EGF-induced phosphorylation/activation of EGFR and ERK1/2 in breast cancer cells.
A U251

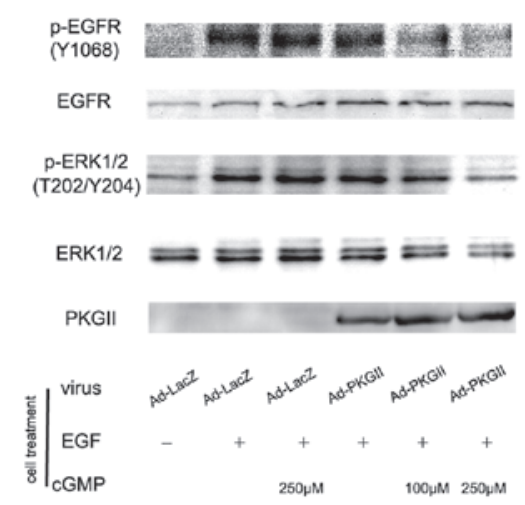

B

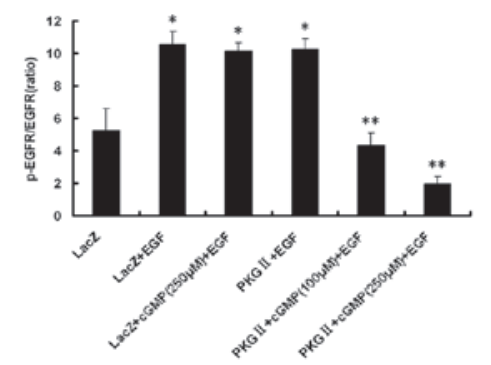

C

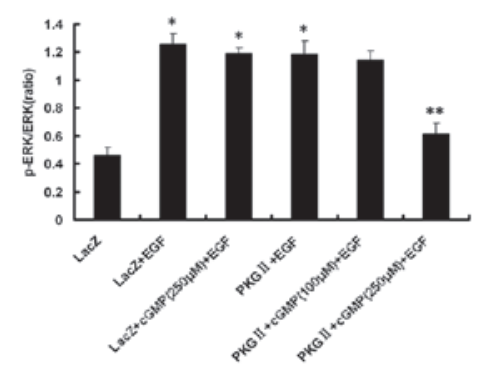

Figure 6. PKG II inhibits the EGF-induced phosphorylation of EGFR and ERK in U251 cells. U251 cells were treated as described in the Materials and methods section. (A) Western blotting revealed that treatment with EGF induced an evident increase in the phosphorylation of EGFR and ERK (Ad-LacZ + EGF group) compared with the control EGF-negative group. Transfection with Ad-PKG II + cGMP efficiently inhibited the EGF-induced phosphorylation of EGFR and ERK (Ad-PKG II + cGMP + EGF groups) compared with the Ad-LacZ + EGF group. (B) Ratio of p-EGFR/EGFR gray levels. (C) Ratio of $\mathrm{p}-\mathrm{ERK} / \mathrm{ERK}$ gray levels. ${ }^{\text {P }}<0.05$ vs. Ad-LacZ control group. ${ }^{* *} \mathrm{P}<0.05$ vs. Ad-LacZ + EGF, Ad-PKG II + cGMP + EGF and PKG II + EGF groups. The results are representative of three separate experiments. cGMP, cyclic guanosine monophosphate; PKG II, type II cGMP-dependent protein kinase; EGF, epidermal growth factor; EGFR, EGF receptor; Ad-LacZ/ PKG II, adenoviral vectors encoding $\beta$-galactosidase/PKG II cDNA.

PKG II inhibits EGF-induced phosphorylation of EGFR and ERK1/2 in U251 cells. The U251 cell line was established through explant culture of glioblastoma (astrocytoma) tissue from a 75 year-old male (13). The inhibitory effect of PKG II on the phosphorylation of EGFR and ERK1/2 in the U251 cells was investigated by western blotting. The results revealed that transfection with Ad-PKG II (Ad-PKG II group) caused an evident increase in the expression of PKG II compared with the Ad-LacZ control group. Treatment with $100 \mathrm{ng} / \mathrm{ml}$ EGF for 5 min (Ad-LacZ + EGF group) caused a marked increase in the phosphorylation of EGFR and ERK1/2 compared with the control EGF-negative group $(\mathrm{P}<0.05$; Fig. 6). In cells transfected with Ad-PKG II, stimulated with 8-pCPT-cGMP 
and incubated with EGF (Ad-PKG II + cGMP + EGF group), the EGF-induced phosphorylation of EGFR and ERK1/2 was significantly decreased compared with the Ad-LacZ + EGF group $(\mathrm{P}<0.05$; Fig. 6$)$. This indicated that $\mathrm{PKG}$ II inhibited the EGF-induced phosphorylation/activation of EGFR and ERK1/2 of glioblastoma cells.

\section{Discussion}

EGFR is a member of the ErbB receptor tyrosine kinase family, which includes ErbB1 (EGFR), ErbB2 (HER2), ErbB3 (HER3) and ErbB4 (HER4). EGFR is a $170-\mathrm{kDa}$ protein composed of extracellular, transmembrane and cytoplasmic domains (14). The activation of EGFR depends upon ligand binding and the subsequent dimerization and autophosphorylation of the receptor. Following activation, EGFR recruits effector proteins to its phosphorylated C-terminal sub-domain and initiates effector protein-mediated signaling mechanisms. Previous data indicate that EGFR is closely associated with tumorigenesis, and that overexpression and mutation of EGFR occurs in the majority of cancers (15). In vitro experiments have confirmed that preventing the activation of EGFR can inhibit the proliferation of certain tumor cells (16). In addition, a previous clinical study revealed that cancer patients with overexpressed EGFR often exhibit poorer prognoses (17). EGFR is therefore a potential therapeutic target for the treatment of cancer. Furthermore, techniques that inhibit EGFR activity and its associated signal transduction pathways have been extensively researched, including the use of specific antibodies against EGFR, and the application of agents that inhibit the function of EGFR (18).

PKG II was at first believed to be implicated in certain physiological functions, including learning and memory, intestinal secretion and bone growth (19). However, novel functions of PKG II have been identified, including an involvement in mechano-signal transduction in osteoblasts, and in the regulation of sodium channels $(20,21)$. In addition, previous studies have indicated that PKG II may be a potential cancer suppressor due to its role in the regulation of proliferation and apoptosis in cancer cells $(22,23)$. Previous studies have demonstrated that PKG II inhibits the EGF-induced Tyr1068 phosphorylation of EGFR and the Thr202/Tyr204 phosphorylation of ERK1/2 in gastric cancer cells $(22,24)$. The present study aimed to determine whether PKG II exhibits an inhibitory effect upon the activation of EGFR and ERK1/2 in different cancer cell lines. The results revealed that PKG II exhibited an inhibitory effect upon the activation of EGFR and MAPK/ERK in cell lines obtained from a number of cancerous tissues, namely colon, hepatic, renal, lung and breast cancer tissues, and also from glioma. This confirmed that PKG II exhibits a wide range of inhibitory effects upon the activation of EGFR and its downstream signaling pathways in different cancer cells, which provides further evidence to support the use of PKG II as a potential cancer suppressor agent.

\section{Acknowledgements}

This study was supported by grants from the National Natural Science Foundation of China (grant nos. 81272755,
31040002 and 81201959). The authors would like to thank Dr Gerry Boss and Dr Renate Pilz of the University of California, San Diego for providing the adenoviral constructs.

\section{References}

1. Cook AL and Haynes JM: Protein kinase G II-mediated proliferative effects in human cultured prostatic stromal cells. Cell Signal 16: 253-261, 2004.

2. Swartling FJ, Ferletta M, Kastemar M, et al: Cyclic GMP-dependent protein kinase II inhibits cell proliferation, Sox9 expression and Akt phosphorylation in human glioma cell lines. Oncogene 28: 3121-3131, 2009.

3. Fallahian F, Karami-Tehrani F, Salami S and Aghaei M: Cyclic GMP induced apoptosis via protein kinase G in oestrogen receptor-positive and -negative breast cancer cell lines. FEBS J 278: 3360-3369, 2011.

4. Wang R, Kwon IK, Thangaraju M, et al: Type 2 cGMP-dependent protein kinase regulates proliferation and differentiation in the colonic mucosa. Am J Physiol Gastrointest Liver Physiol 303: G209-G219, 2012.

5. Chen YC, Ren F, Sang JR, et al: Type II cGMP-dependent protein kinase inhibits proliferation of the gastric cancer cell line BGC-823. Mol Med Rep 3: 361-366, 2010.

6. Jiang L,Lan T, Chen YC, etal: PKGII inhibitsEGF/EGFR-induced migration of gastric cancer cells. PLoS One 8: e61674, 2013.

7. Morandell S, Stasyk T, Skvortsov S, et al: Quantitative proteomics and phosphoproteomics reveal novel insights into complexity and dynamics of the EGFR signaling network. Proteomics 8: 4383-4401, 2008.

8. Fogh J, Fogh JM and Orfeo T: One hundred and twenty-seven cultured human tumor cell lines producing tumors in nude mice. J Natl Cancer Inst 59: 221-226, 1977.

9. Knowles BB, Howe CC and Aden DP: Human hepatocellular carcinoma cell lines secrete the major plasma proteins and hepatitis B surface antigen. Science 209: 497-499, 1980.

10. Kinouchi T, Kotake T, Mori Y and Abe T: Human renal cell carcinoma: establishment and characterization of a new cell line (OS-RC-2). In Vitro Cell Dev Biol 21: 195-199, 1985.

11. Giard DJ, Aaronson SA, Todaro GJ, et al: In vitro cultivation of human tumors: establishment of cell lines derived from a series of solid tumors. J Natl Cancer Inst 51: 1417-1423, 1973.

12. Brooks SC, Locke ER and Soule HD: Estrogen receptor in a human cell line (MCF-7) from breast carcinoma. J Biol Chem 248: 6251-6253, 1973.

13. Zhou YX, Huang YL, Xu QN, et al: Several monomes from Tripterygium wilfordii inhibit proliferation of glioma cells in vitro. Ai Zheng 21: 1106-1108, 2002 (In Chinese).

14. Prigent SA and Lemoine NR: The type I (EGFR-related) family of growth factor receptors and their ligands. Prog Growth Factor Res 4: 1-24, 1992.

15. Normanno N, Bianco C, De Luca A, et al: Target-based agents against ErbB receptors and their ligands: a novel approach to cancer treatment. Endocr Relat Cancer 10: 1-21, 2003.

16. Sharma SV, Bell DW, Settleman J and Haber DA: Epidermal growth factor receptor mutations in lung cancer. Nat Rev Cancer 7: 169-181, 2007.

17. Hynes NE and MacDonald G: ErbB receptors and signaling pathways in cancer. Curr Opin Cell Biol 21: 177-184, 2009.

18. Quatrale AE, Porcelli L, Silvestris N, et al: EGFR tyrosine kinases inhibitors in cancer treatment: in vitro and in vivo evidence. Front Biosci (Landmark Ed) 16: 1962-1972, 2011.

19. Hofmann F: The biology of cyclic GMP-dependent protein kinases. J Biol Chem 280: 1-4, 2005.

20. Rangaswami H, Marathe N, Zhuang S, et al: Type II cGMP-dependent protein kinase mediates osteoblast mechanotransduction. J Biol Chem 284: 14796-14808, 2009.

21. Nie HG, Chen L, Han DY, et al: Regulation of epithelial sodium channels by cGMP/PKGII. J Physiol 587: 2663-2676, 2009.

22. Wu Y, Chen YC, Qu R, et al: Type II cGMP-dependent protein kinase inhibits EGF-triggered signal transduction of the MAPK/ERK-mediated pathway in gastric cancer cells. Oncol Rep 27: 553-558, 2010.

23. Lan T, Chen Y, Sang J, et al: Type II cGMP-dependent protein kinase inhibits EGF-induced MAPK/JNK signal transduction in breast cancer cells. Oncol Rep 27: 2039-2044, 2012.

24. Jiang L, Chen Y, Li Y, et al: Type II cGMP-dependent protein kinase inhibits ligand-induced activation of EGFR in gastric cancer cells. Mol Med Rep 9: 1405-1409, 2014. 